\title{
APLIKASI TEKNOLOGI EKSPLORASI UNTUK MEMAHAMI KONDISI AIR TANAH DI DAERAH PADANG LUAS KABUPATEN TANAH LAUT
}

\author{
Teguh Prayogo \\ Pusat Teknologi Sumberdaya Mineral, BPPT \\ JI. MH. Thamrin No. 8 Jakarta Pusat
}

\begin{abstract}
Groundwater is water that comes from the ground. Groundwater comes from rain, snow, sleet, and hail that soaks into the ground. The water moves down into the ground because of gravity, passing between particles of soil, sand, gravel, or rock until it reaches a depth where the ground is filled, or saturated, with water. Groundwater is stored in the ground in materials like gravel or sand. Water can also move through rock formations like sandstone or through cracks in rocks. Groundwater is one of solution to overcome a problem of the need of drinking water in the Padang Luas Area, because the availability of surface water is not enough. The objective of research is finding out characteristic and condition of ground water in Padang Luas, Tanah Laut district. To meet the objective, it was applied method of geophysical technology, namely electrical resistivity method by injecting current into the ground through current electrodes that are grounded at the earth's surface and measuring the difference of the electrical potential between the potential electrodes. Based on data processing, modeling and interpretation, it was gained result concerning the existence of aquifer in Padang Luas area that is predicted to occupy between $30-60$ meter and $70-120$ meter depth.
\end{abstract}

Keywords : Groundwater, Electrical Resistivity

\section{PENDAHULUAN}

\subsection{Latar Belakang}

Air merupakan karunia Allah yang sangat besar bagi kehidupan umat manusia dan makhluk hidup lainnya di bumi. Tidak ada suatu makhluk hidup pun yang bisa bertahan hidup tanpa air. Air dibutuhkan manusia untuk memenuhi berbagai macam kebutuhan hidup, misalnya untuk keperluan air minum dan rumah tangga, pertambangan, pertanian, perkebunan, perumahan, industri, perhubungan, pariwisata dan lain-lain.

Sumber utama air yang ada di permukaan dan bawah permukaaan tanah berasal dari hujan. Hujan yang turun ke bumi sebagian akan mengalir sebagai air permukaan dan sebagian lagi meresap ke dalam tanah, kemudian membentuk air tanah. Baik air permukaan maupun air tanah mengalir dari daerah yang lebih tinggi yaitu dari daerah resapan atau daerah imbuhan menuju daerah yang lebih rendah dan akhirnya menuju ke laut ${ }^{1}$.

Air tanah sebagai salah satu komponen penting dari sumberdaya air mempunyai peranan yang sangat berarti bagi penyediaan air untuk memenuhi kebutuhan pokok makhluk hidup. Keberadaan air tanah yang hampir dapat ditemui di setiap lahan tanah menyebabkan sumber daya ini menjadi andalan utama terutama bagi penyediaan kebutuhan sehari-hari penduduk. Oleh karena itu, air tanah masih menjadi andalan bagi masyarakat untuk digunakan sebagai sumber pasokan air bersih baik untuk memenuhi keperluan rumah tangga maupun untuk menunjang usaha komersial.

Hidrologi Kabupaten Tanah Laut terdiri atas sungai dan danau yang merupakan sumber daya air permukaan. Fungsi-fungsi sungai tersebut adalah untuk sumber air minum, pengairan, usaha perikanan dan sebagai sarana transportasi antara daerah timur dengan daerah Barat di Kabupaten Tanah Laut. Pada musim hujan terdapat wilayah yang terkena banjir, baik terus menerus tergenang maupun tergenang secara periodik ${ }^{2)}$.

Kedalaman air tanah di suatu wilayah antara lain ditentukan oleh tinggi wilayah dari permukaan laut, jenis batuan induk dan sebagainya. Wilayah Kabupaten Tanah Laut tersusun dari batuan induk yang bervariasi dan terletak pada ketinggian $0-1000 \mathrm{~m}$ dpl. Oleh sebab itu kedalaman air tanahnya akan bervariasi, dari dangkal (daerah pantai hingga perbukitan dan pegunungan).

Kebutuhan air bersih seringkali tidak bisa hanya dengan mengandalkan air permukaan, 
karena pada daerah tertentu air permukaan tersedia dalam jumlah yang terbatas, atau kalaupun cukup tersedia, namun kualitasnya belum memenuhi standar mutu untuk dimanfaatkan. Salah satu alternatif mengatasi kekurangan air bersih adalah dengan cara melakukan pencarian sumberdaya air bawah tanah yang kedalamannya bisa mencapai 150 meter, dimana air tanah semacam ini cukup bisa diandalkan untuk memenuhi kebutuhan masyarakat.

Permasalahan air bersih seperti tersebut di atas juga dialami oleh masyarakat daerah Padang Luas, dimana mereka mengalami kesulitan untuk mendapatkan air bersih bagi kehidupan penduduk sehari-hari. Penerapan teknologi eksplorasi merupakan salah satu cara untuk mencari dan menggambarkan potensi sumberdaya alam, misalnya sumberdaya air tanah. Metoda teknologi eksplorasi yang dimaksud adalah teknologi eksplorasi geofisika yang bersifat dinamis, yang dikembangkan untuk melakukan akuisisi data keberadaan air bawah permukaan dan mendeteksi potensi air bawah permukaan dengan mempertimbangkan kajian literatur dan kondisi lapangan di daerah survei.

Tulisan ini membahas tentang penerapan teknologi eksplorasi untuk mengkaji sumberdaya air tanah di daerah Padang Luas, Kabupaten Tanah Laut.

\subsection{Tujuan}

Tujuan penelitian ini adalah mengetahui gambaran mengenai kondisi air tanah di daerah Padang Luas dengan menerapkan teknologi eksplorasi geofisika.

\section{LOKASI PENELITIAN DAN KESAMPAIAN DAERAH}

Penelitian dan pengkajian sumberdaya air ini dilakukan di daerah Padang Luas, kecamatan Kurau, Kabupaten Tanah Laut, Propinsi Kalimantan Selatan sebagaimana disajikan pada peta Gambar 1 dan Error! Reference source not found. 3). Kabupaten Tanah Laut ini terletak disebelah Selatan sisi barat dari Propinsi Kalimantan Selatan yang dibatasi oleh :

- Sebelah barat : Laut Jawa

- Sebelah timur : Kab. Tanah Bumbu

- Sebelah selatan : Laut Jawa

- Sebelah utara : Kab. Banjar

Secara Geografis, kabupaten Tanah Laut terletak di antara 11430'20" sampai dengan 115²3'31" Bujur Timur dan 330'33" sampai dengan 411'38" Lintang Selatan.
Lokasi penelitian (Desa Padang Luas) ini merupakan salah satu desa di kecamatan Kurau yang terletak relatif di bagian tengah dari kecamatan Bati-Bati dan berdekatan dengan jalan utama trans Kalimantan. Desa Padang Luas ini berjarak sekitar $43 \mathrm{~km}$ dari kota Pelaihari, Ibukota Kabupaten Tanah Laut.

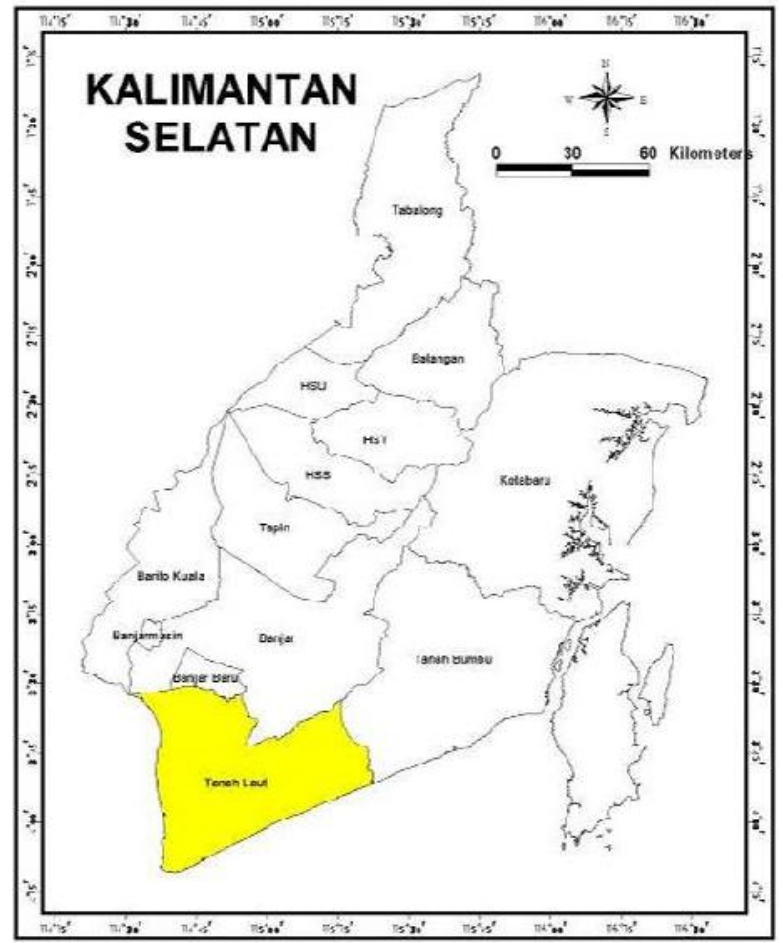

Gambar 1. Kabupaten Tanah Laut (warna abu-abu).

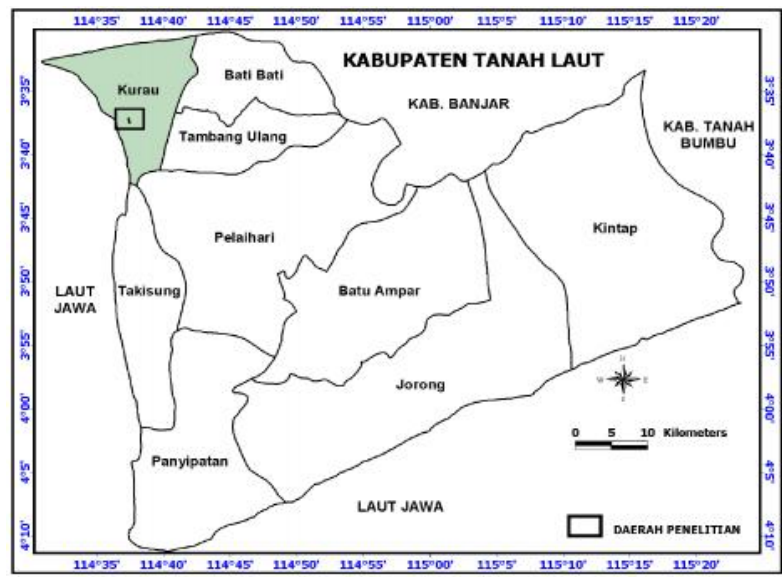

Gambar 2. Peta Administrasi Kabupaten Tanah Laut (warna abu-abu = Kecamatan Kurau)

\section{METODOLOGI}

Metodologi yang diterapkan dalam penelitian ini secara garis besar terdiri dari studi pendahuluan, survei lapangan (survei eksplorasi geofisika), analisis dan interpretasi. 


\section{a. Studi Pendahuluan}

Pekerjaan Studi Pendahuluan ini dilaksanakan dengan melakukan kegiatan tinjauan pustaka, inventarisasi data dan informasi, penyiiapan peta-peta dasar kerja, dan penentuan rencana survei (mobilisasi tim dan peralatan).

\section{b. Survei Lapangan}

Pekerjaan survei lapangan ini merupakan pekerjaan survei air tanah dengan memanfaatkan teknologi eksplorasi geofisika yang diaplikasikan pada daerah penelitian (Padang Luas) untuk mendapatkan nilai-nilai tahanan jenis pada daerah yang diukur.

Pekerjaan eksplorasi geofisika ini dengan memanfaatkan salah satu metoda geofisika yang berisfat dinamis yang dikembangkan untuk mendeteksi kondisi bawah permukaan (keberadaan akuifer) dengan menginjeksikan arus listrik kedalam bumi, selanjutnya di permukaan bumi diukur nilai kuat arus (I) dan beda potensial (V) titik-titik injeksi arus tersebut.

Pekerjaan survei lapangan ini meliputi pekerjaan penentuan arah lintasan pengukuran geofisika, pngeplotan/pencatatan posisi koordinat lokasi pengukuran, pemasangan elektroda (arus dan potensial) dan peralatan lainnya, pengujian atau pengetesan hubungan antar peralatan, pengukuran nilai tahanan jenis dan pencatatan hasil pengukuran.

\section{c. Analisis dan Interpretasi}

Pekerjaan analisis ini merupakan pekerjaan studio yang dilakukan untuk memberikan gambaran tentang kondisi dan keberadaan air tanah (akuifer) dengan melakukan pekerjaan penghitungan nilai-nilai terukur, korelasi antar tiitk pengukuran, pemodelan dan interpretasi hasil survei lapangan di daerah penelitian.

\section{PERALATAN YANG DIGUNAKAN}

Peralatan yang digunakan pada survey sumberdaya air tanah di daerah Padang Luas ini terdiri dari :

- Global Positioning System (GPS)

- Resistivitymeter merk OYO

- Accu baterai

- Kabel dan elektroda

- Kompas Geologi

- Meteran

- Peralatan penunjang lainnya.

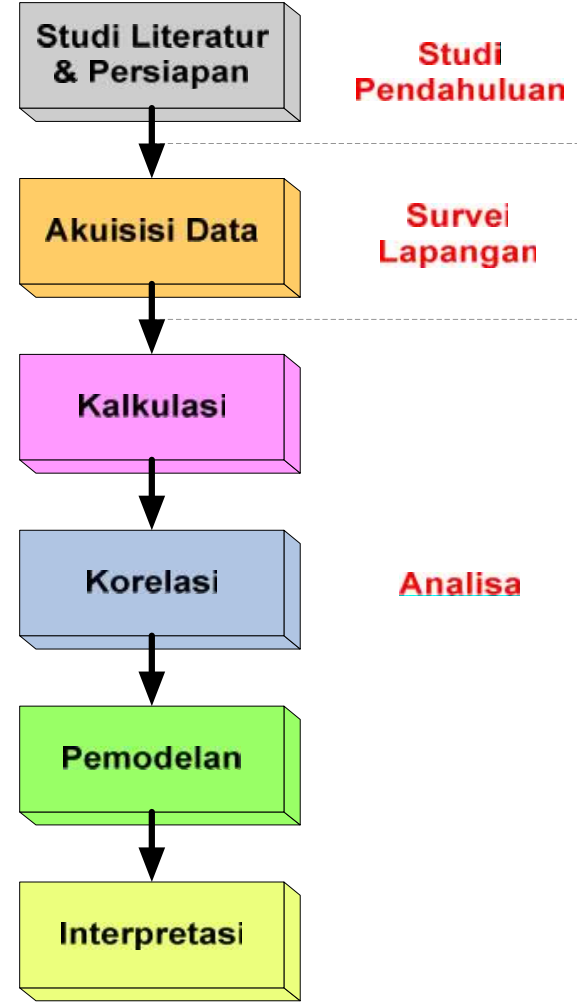

Gambar 3. Metodologi Penelitian

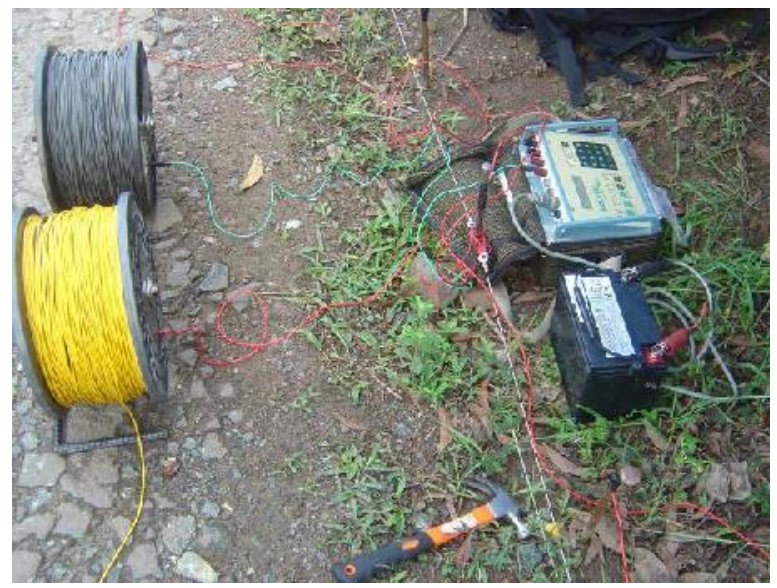

Gambar 4. Peralatan survey lapangan

\section{HASIL DAN PEMBAHASAN}

Pekerjaan survey pada kegiatan penelitian ini adalah difokuskan pada pekerjaan pendugaan sumberdaya air tanah, dimana komponen-komponen yang diamati dan diukur adalah nilai-nilai tahanan jenis bawah permukaan dari daerah yang diukur. Metoda yang dipergunakan dalam pengukuran geofisika ini adalah metoda 1D (Metoda Schlumberger). dimana hasil yang diharapkan adalah penetrasi yang lebih dalam yang digambarkan dalam 1 dimensi seperti lubang bor. 
Pada metoda geolistrik 1D, pembahasan mengenai aliran listrik dalam bumi didasarkan pada asumsi bahwa bumi merupakan medium homogen isotropis. Jadi, lapisan batuan di bawah permukaan bumi diasumsikan berbentuk berlapis-lapis.

Metoda schlumberger yang diterapkan adalah metoda Vertical electrical Sounding (VES). Pada metoda ini digunakan 2 elektroda arus dan 2 elektroda potensial, dimana susunan elektrodanya mempunyai spasi yang berubahubah ${ }^{4)}$. Hasil akhirnya adalah sebaran resistivity pada arah vertical (seperti data bor). Masingmasing titik sounding selanjutnya dikorelasikan untuk iinterpretasi kedalaman akuifer di daerah penyelidikan. Visualisasi sistem pengukurannya dapat dilihat pada gambar 5

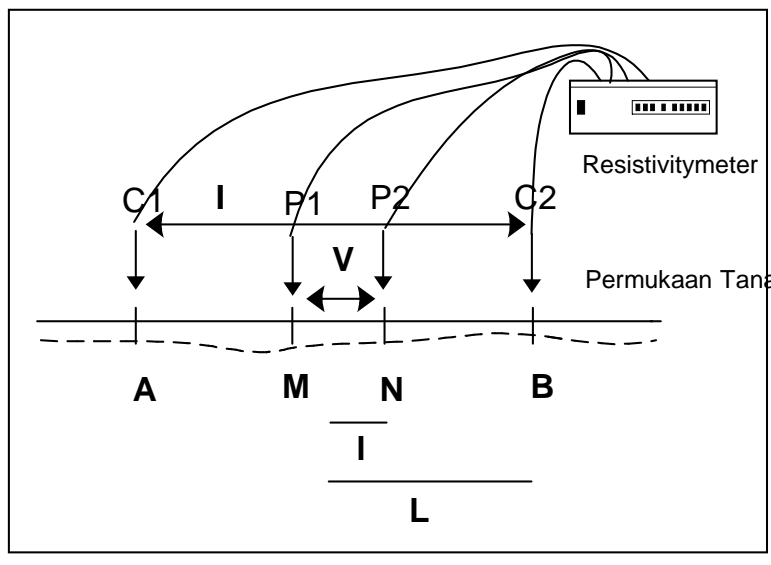

Gambar 5. Visualisasi Pengukuran Tahanan Jenis 1D Konfigurasi Schlumberger 4\&5)

Dimana $\mathrm{M}, \mathrm{N}$ adalah elektroda potensial, sedangkan A dan B adalah elektroda arus. Untuk Konfigurasi Schlumberger, tahanan jenis didapatkan dari persamaan sebagai berikut :

$$
\begin{gathered}
\rho_{s}=K_{s} \frac{\Delta V}{I} \text { dan } \\
K_{s}=\frac{\pi\left(L^{2}-l^{2}\right)}{2 l}
\end{gathered}
$$

dimana $\rho$ adalah tahanan jenis semu, $\mathrm{K}$ adalah faktor geometri, I adalah besarnya arus listrik yang diinjeksikan ke dalam bumi, $\mathrm{V}$ adalah beda potensial yang terukur, $\ell$ adalah setengah spasi antara P1 - P2 (setengah jarak antara elektroda potensial), dan $L$ adalah setengah spasi antara C1 - C2 (setengah jarak antara elektroda arus) ${ }^{4}$.

Pekerjaan survei geolistrik pada daerah Padang Luas ini terdiri dari 3 titik pengukuran atau lintasan geolistrik, dimana panjang total tiap lintasan sekitar 1000 meter. Secara umum arah lintasan geolistriknya berarah utara - selatan atau relatif sejajar dengan arah utara peta seperti terlihat pada gambar 6 .

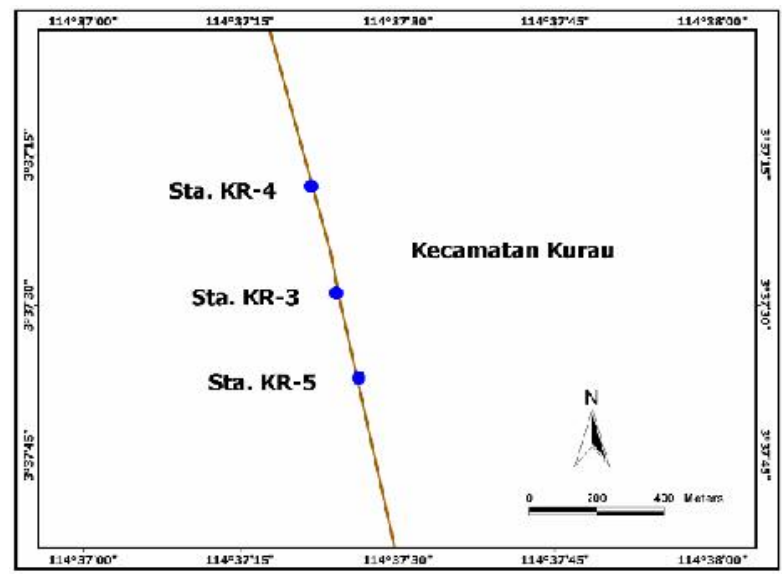

Gambar 6. Peta Lokasi pengukuran geofisika di daerah Padang Luas, Kab. Tanah Laut

Tabel 1. Titik-titik pengukuran di daerah Padang Luas, Kab. Tanah Laut

\begin{tabular}{|l|c|c|c|}
\hline \multirow{2}{*}{ No } & \multirow{2}{*}{ Lokasi } & \multicolumn{2}{|c|}{ Koordinat } \\
\cline { 3 - 4 } & & Lintang & Bujur \\
\hline 1. & Sta.KR-3 & $3^{\circ} 37^{\prime} 28^{\prime \prime} S$ & $114^{\circ} 37^{\prime} 24^{\prime \prime} \mathrm{E}$ \\
\hline 2. & Sta.KR-4 & $3^{\circ} 37^{\prime} 18^{\prime \prime} S$ & $114^{\circ} 37^{\prime} 21^{\prime \prime} \mathrm{E}$ \\
\hline 3. & Sta.KR-5 & $3^{\circ} 37^{\prime} 37^{\prime \prime} S$ & $114^{\circ} 37^{\prime} 26^{\prime \prime} \mathrm{E}$ \\
\hline
\end{tabular}

Pada pekerjaan survei lapangan dengan penerapan teknologi eksplorasi geofisika ini akan diperoleh 3 kumpulan nilai-nilai tahanan jenis. Oleh karena itu, kurva penampang tahanan jenis atau kolom penampang tahanan jenis yang dihasilkan juga akan berjumlah 3 , dimana akan memberikan kenampakan seperti log bor.

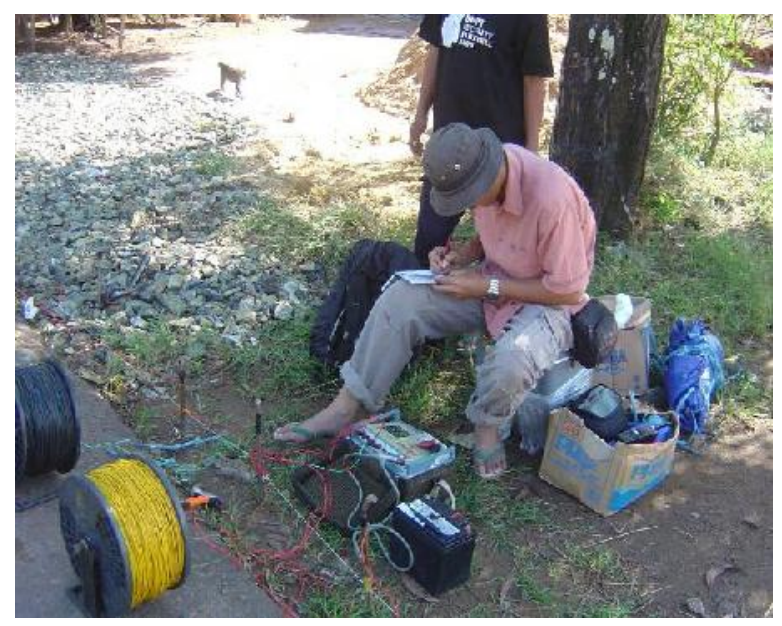

Gambar 7. Pengukuran dan pencatatan nilai-nilai tahanan jenis di lapangan 
Selanjutnya hasil pengukuran nilai-nilai tahanan jenis dari survei geofisika di lapangan tersebut diolah menggunakan suatu aplikasi (perangkat lunak), sehingga menghasilkan 3 kurva tahanan jenis (stasiun pengukuran sta.KR3, sta.KR-4 dan sta.KR-5) yang diplot pada kurva logaritma. Ketiga kurva hasil pengolahan tahanan jenis tersebut dapat dilihat pada gambar 8.
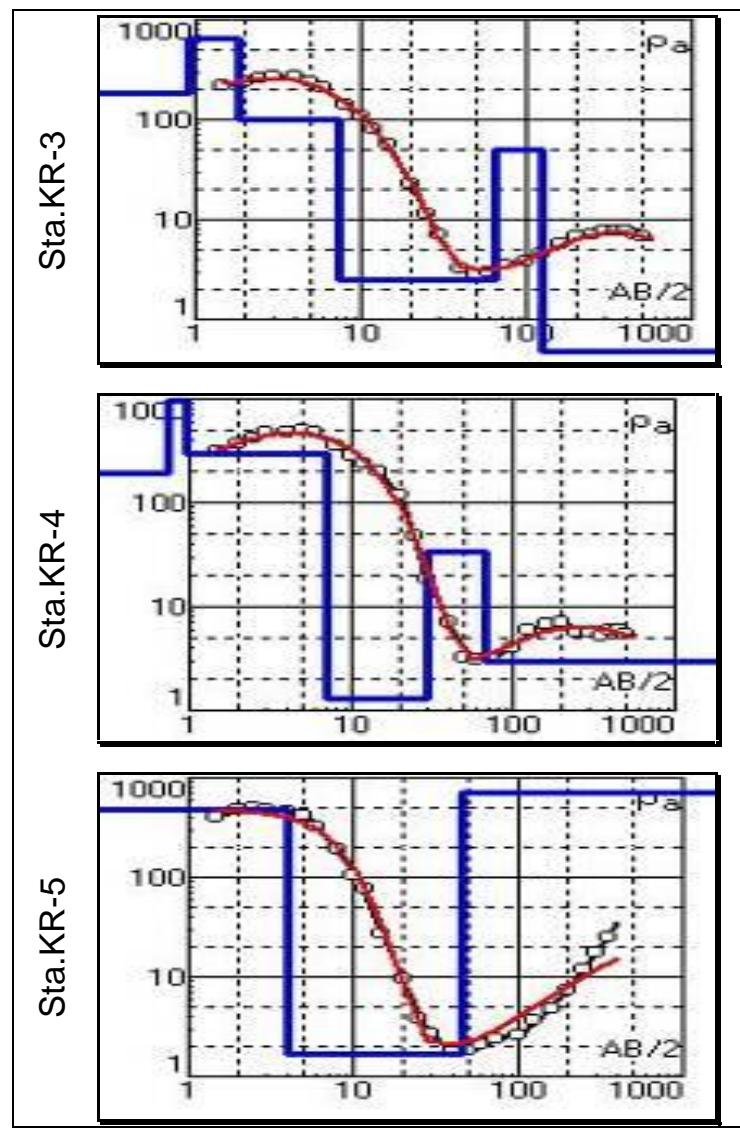

Gambar 8. Kurva Penampang Tahanan Jenis di 3 lokasi pengukuran geofisika di daerah penelitian

Hasil pengeplotan nilai-nilai tahanan jenis pada kurva logaritma yang berupa kurva tahanan jenis terlihat pada gambar 8 di atas. Selanjutnya dikorelasikan dengan nilai kedalaman dari permukaan tanah untuk menghasilkan keterkaitan atau hubungan diantara ketiga kurva tahanan jenis tersebut.

Gambar 9 di bawah ini memperlihatkan gambaran hasil korelasi atau keterkaitan antara nilai tahanan jenis dan kedalaman pada ketiga lokasi pengukuran geofisika di daerah survey. Hasil pengolahn data tahanan jenis seperti pada gambar 9 di atas dijadikan sebagai dasar untuk memperoleh suatu penampang 1 dimensi (1D) yang menggambarkan segementasi kedalaman yang disertai dengan nilai tahanan jenisnya. Gambaran tentang segementasi trsebut dapat dilihat pada Gambar 10.

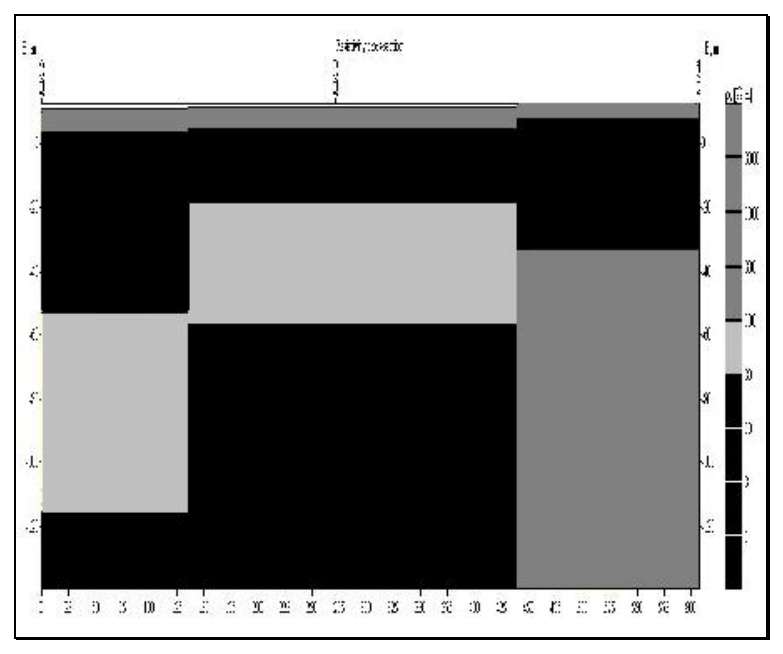

Gambar 9. Penampang Tahanan Jenis hasil korelasi di 3 lokasi pengukuran.

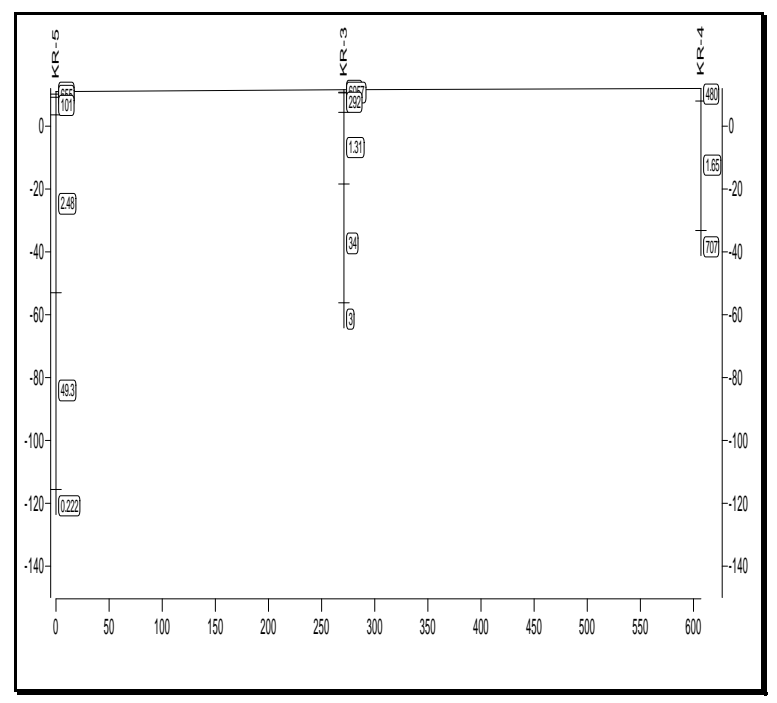

Gambar 10. Penampang 1 Dimensi yang menggambarkan kedalaman dan nilai tahanan jenisnya

Pekerjaan berikutnya adalah interpretasi dan analisa terhadap hasil pengolahan geofisika di atas dengan mempertimbangkan faktor-faktor yang bisa membantu dalam interpretasi, seperti kondisi geologi, kondisi lapangan, kondisi geohidrologi, dan sebagainya, untuk mendapatkan model penampang geologinya dan gambaran kondisi air tanah di daerah yang di teliti.

Gambar 11 mengilustrasikan hasil interpretasi dan analisa nilai tahanan jenis pada daerah penelitian yang berupa model penampang geologi. Nilai tahanan jenis $<30 \mathrm{~m}$ diindikasikan dengan warna abu-abu gelap, warna abu-abu terang mewakili tahanan jenis bernilai $30-100 \mathrm{~m}$, dan nilai tahanan jenis > $100 \mathrm{~m}$ ditampilkan dengan warna hitam. 


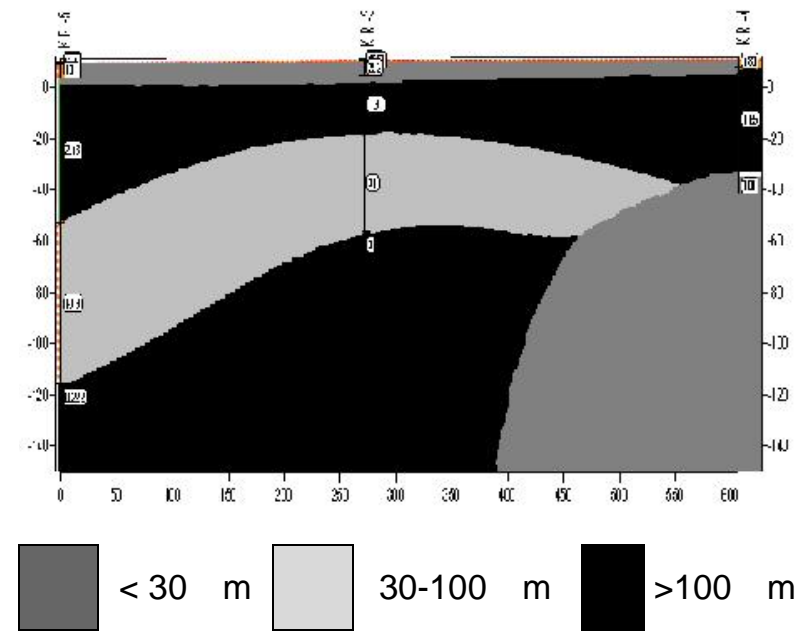

Gambar 11. Model Penampang Geologi hasil interpretasi tahanan jenis di daerah penelitian

Pekerjaan pengukuran geofisika di lapangan, pengolahan data, dan pemodelan, memberikan hasil nilai tahanan jenis yang bervariasi dari 1 Ohm-m sampai dengan > 100 Ohm-m. Pertimbangan dan keterkaitan dengan kondisi geologi daerah penelitian dan data referensi harga tahanan jenis beberapa batuan, dijadikan acuan untuk interpretasi jenis litologi yang ada di daerah survey. Tabel 2 memperlihatkan jenis litologi di daerah penelitian.

Tabel 2. Nilai tahanan jenis dan interpretasi litologinya di daerah penelitian

\begin{tabular}{|c|l|}
\hline $\begin{array}{c}\text { Resistivity } \rho \\
\text { (Ohm-m) }\end{array}$ & \multicolumn{1}{|c|}{ Interpretasi Litologi } \\
\hline$<20 \mathrm{~m}$ & Lempung \\
\hline $30-100 \mathrm{~m}$ & $\begin{array}{l}\text { Endapan lanau-pasir, akuifer air } \\
\text { tanah potensial }\end{array}$ \\
\hline$>100 \mathrm{~m}$ & $\begin{array}{l}\text { Endapan permukaan dan atau } \\
\text { batuan keras }\end{array}$ \\
\hline
\end{tabular}

Berdasarkan hasil pemodelan geologi seperti pada gambar 11, maka tampak bahwa di daerah penelitian didominasi sebagian besar oleh nilai tahanan jenis yang rendah $(<30 \quad \mathrm{~m})$ yang diinterpretasikan sebagai lapisan lempung (lapisan impermeable) dan sebagian kecil oleh tahanan jenis yang bernilai lebih besar yaitu 30 $100 \mathrm{~m}$, yang diintepretasikan dengan litologi lanau sampai pasir. Sedangkan tahanan jenis yang bernilai $>100 \mathrm{~m}$ diinterpretasikan dengan endapan permukaan dan atau batuan keras.

Lapisan batuan yang berpotensi sebagai akuifer air tanah adalah batuan yang mempunyai porositas dan permeabilitas cukup besar (misalnya lapisan pasir / batupasir). Berdasarkan hasil interpretasi tahanan jenis di daerah penelitian, kemungkinan terdapatnya air tanah adalah sebagai berikut :

Pada daerah Padang Luas ini, lapisan batuan yang berpotensi sebagai akuifer air tanah di lokasi Sta.KR-5 adalah pada kedalaman 64 $126 \mathrm{~m}$, di lokasi Sta.KR--3 potensi akuifer air tanahnya pada kedalaman 29,9 - 67,7 m dan pada lokasi Sta.KR--4 tidak dijumpai lapisan batuan yang berpotensi sebagai akuifer air tanah. Berdasarkan kenyataan di atas menunjukkan bahwa di daerah Padang Luas Kecamatan Kurau mempunyai akuifer air tanah yang relatif dalam, karena lapisan permukaannya mempunyai lapisan lempung yang tebal $(22,8-56,6 \mathrm{~m})$.

Luasan dan jumlah titik pengukuran geofisika yang relatif sedikit dan tebalnya lapisan lempung yang ada, mempersulit untuk menafsirkan distribusi muka air tanah di daerah penelitian. Meskipun demikian, arah aliran air tanah di daerah penelitian secara umum dapat ditafsirkan sebagai berikut :

Berdasarkan posisi geografis titik pengukuran geolistrik seperti gambar 6 dan hasil pemodelan dan interpretasi nilai-nilai tahanan jenis seperti pada gambar 11, maka pada daerah Padang Luas Kecamatan Kurau ini, aliran air tanah relatif mengalir dari lokasi Sta.KR-4 mengalir ke lokasi Sta.KR-3, dan Sta.KR-5. Atau aliran air tanahnya relatif mengalir dari utara ke arah selatan atau ke arah bawah dari peta.

Apabila dikorelasikan dengan kondisi geohidrologi regional di sekitar daerah kabupaten Tanah Laut, maka hasil penelitian ini menunjukkan bahwa keberadaan lapisan batuan yang berpotensi sebagai akuifer air tanah di daerah peneltiian tidak selalu dijumpai. Hal ini adalah sesuatu yang tidak terelakkan, karena daerah penelitian merupakan daerah dengan akuifer yang penyebarannya bersifat setempatsetempat berupa lensa-lensa akuifer dengan keterusan yang beragam ${ }^{2)}$.

Aktifitas eksploitasi air tanah di daerah penelitian bisa dilakukan engan memperhatikan kondisi air tanah di daerah ini, yaitu pemboran untuk mendapatkan lapisan potensi akuifer air tanah bisa dilakukan pada kisaran kedalaman diatas 30 meter di sekitar lokasi Sta.KR-3, dan kisaran kedalaman diatas 70 meter disekitar lokasi Sta.KR-5.

\section{KESIMPULAN}

Berdasarkan hasil pemodelan dan interpretasi di daerah Padang Luas, Kecamatan Kurau, Kabupaten Tanah Laut, maka secara garis besar dapat disimpulkan sebagai berikut :

- Teknologi eksplorasi geofisika dapat digunakan untuk memahami kondisi air tanah di daerah yang mengalami kesulitan air, dan membantu memecahkannya. 
- Lapisan potensi pembawa akuifer air tanah pada darah penelitian (Padang Luas) ditafsirkan berada pada kedalaman yang cukup dalam dan bervariasi yaitu pada kisaran kedalaman diatas 30 meter dan diatas 70 meter.

- Aliran air tanah di daerah penelitian (Padang Luas) diperkirakan relatif mengalir dari utara ke arah selatan.

- Pemboran eksploitasi untuk mendapatkan lapisan potensi akuifer air tanah pada daerah penelitian bisa dilakukan pada kisaran kedalaman diatas 30 meter di sekitar lokasi Sta.KR-3, dan kisaran kedalaman diatas 70 meter disekitar lokasi Sta.KR-5.

\section{DAFTAR PUSTAKA}

1. Danaryanto dkk, 2005, "Air Tanah di Indonesia dan Pengelolaannya", Departemen Energi dan Sumberdaya Mineral.

2. Haryadi T dkk, 2004, "Peta Hidrogeologi Indonesia Lembar IX daerah Banjarmasin dan sekitarnya Skala 1:1.000.000", Direktorat Geologi Tata Lingkungan dan Kawasan pertambangan, Departemen Energi dan Sumber Daya Minreal (ESDM).

$3 . \longrightarrow$ 2005, "Profil Daerah Kabupaten Tanah Laut", http://tanahlautkab.go.id/

$4 . \quad$, 2005, "Kabupaten Tanah Laut Dalam Angka 2005", Badan Pusat Statistik Kabupaten Tanah Laut, Badan Perencanaan Pembangunan Daerah.

5. W.Lowrie, 2007, "Geoelectricity", Fundamentals of Geophysics p. 252-276, Second Edition, Cambridge University Press.

6. W.D.Weight, 2004, "Basics Geophysics oh The Shallow Subsurface", Manual of Applied Field Hydrogeology p.121-164, The McGrawHill Companies. 